\title{
Problematika Kebijakan Pendidikan Di Tengah Pandemi Dan Dampaknya Terhadap Proses Pembelajaran Di Indonesia
}

\author{
Ahmad Muzawir Saleh \\ Universitas Islam Negeri Alauddin Makassar \\ ahmadmuzawirs71@gmail.com
}

\begin{abstract}
Abstrak
Pandemi covid-19 telah merubah seluruh tatanan kehidupan manusia, khususnya di dunia pendidikan. Hal tersebut mengharuskan pendidikan berubah dan beradaptasi secara cepat untuk tetap melanjutkan proses pembelajaran. Tujuan dari artikel ini untuk meninjau dampak-dampak yang ditimbukan kebijakan menteri Pendidikan dan Kebudayaan Republik Indonesia tentang Work From Home (WFH) di dunia pendidikan. Artikel ini ditulis dengan meninjau artikel-artikel dan referensi terkait tentang kebijakan pembelajaran online yang dianggap sebagai solusi untuk tetap melanjutkan proses pembelajaran ketika sekolah-sekolah ditutup untuk menghindari penyebaran virus. Namun, di lain sisi kebijakan tersebut telah memberikan dampak terhadap proses tranformasi ilmu pengetahuan baik terhadap peserta didik, guru maupun orang tua atau keluarga.
\end{abstract}

Kata Kunci: Kebijakan, Pandemi Covid-19, Proses Pembelajaran

\section{PENDAHULUAN}

Pandemi Covid-19 merenggut banyak hal dan kemudian membentuk sebuah tatanan hal baru. Pandemi ini pula bagaikan memberikan jalan baru kepada sebuah transformasi baru dalam kehidupan. (Wekke, I. S., \& Saleh, A. M. (2020, August 11). Hal tersebut pula yang menuntut kehidupan untuk berubah dalam kurun waktu yang cepat.

Tuntutan peralihan tersebut yang telah menjamah begitu luas sektor kehidupan, maka pendidikan pula tak lepas dari arus tersebut. Itulah yang kemudian menuntut para pamangku kebijakan sebagai pengayom dan pemberi keputusan atas keberlangsungan dan ketertiban kehidupan telah mengeluarkan kebijakan-kebijakan yang berkaitan dengan pandemi.

Banyak pula Negara yang mengambil kebijakan dengan melakukan penutupan sekolah sebagai langkah menyelamatkan pendidikan dari hantaman bahaya virus, tak terkecuali Indonesia. Penutupan lembaga pendidikan tersebut kemudian bermuara pada kebijakan belajar dari rumah, mengajar dari rumah, atau bekerja dari rumah. Semuanya serba dirumahkan, yang secara otomatis penggunaan media atau ruang akan berganti pula dari offline menuju ke serba online. 
Kebijakan peralihan media pembelajaran ini kepada pembelajaran dalam jaringan yang dilakukan secara online kemudian memberikan berbagai macam problematika di dunia pendidikan. Proses belajar dari rumah merupakan hal yang baru bagi sebahagian keluarga di Indonesia, itu merupakan kejutan besar khususnya bagi produktivitas orang tua yang biasanya sibuk dengan pekerjaannya di luar rumah (Aji, R.H.S.: 2020). Bukan hanya bagi keluarga, tetapi juga berdampak pada kondisi psikologi peserta didik yang biasanya bertatapan langsung namun tiba-tiba harus serba online.

Kebijakan tersebutlah yang kemudian menimbulkan permasalahan baik dari segi pembelajaran, keterampilan, maupun psikologi peserta didik. Belum lagi perbedaan wilayah yang menjadikan bertambahnya permasalahan terkait koneksi ataupun perangkat yang akan digunakan dalam proses pembelajaran.

\section{PEMBAHASAN}

Belajar dari rumah ditetapkan melalui kebijakan yang dikeluarkan oleh Kementerian Pendidikan dan Kebudayaan Republik Indonesia melalui SE nomor 4 tahun 2020 tentang pelaksanaan pendidikan masa darurat penyebaran Corona Virus Desease 2019 (Covid-19). Dari kebijakan tersebutlah kemudian berdampak proses pembelajaran yang ada di sekolah, terutama buat peserta didik, guru, maupun orang tua atau keluarga peserta didik. (Purwanto, A., dkk: 2020).

Proses pembelajaran sebagai sesuatu yang dilami siswa di sekolah sendiri merupakan alat kebijakan publik terbaik sebagai upaya peningkatan pengetahuan dan skill. (Persel, C.H.: 1979) hal yang kemudian juga telah tertanam dalam diri sebagian besar peserta didik adalah sekolah menjadi tempat yang menyenangkan sebagai wahana bermain, berinteraksi dan membangun hubungan serta kesadaran sosial. Sekolah pula menjadi pusat interaksi antara guru dengan peserta didik dalam meningkatkan, pengetahuan, keterampilan serta penanaman sikap dan karakter, maka hal tersebutlah yang kemudian tiba-tiba berhenti saat sekolah pun tiba-tiba ditutup.

Kebijakan yang dikeluarkan tersebut sebagai upaya untuk menyelamatkan peserta didik dari bahaya virus tetapi justru pula akan menimbulkan beberapa dampak khususnya pada peserta didik, guru, dan orang tua. Peserta didik sendiri akan merasa terpaksa belajar dari rumah yang sebenarnya tidak memiliki fasilitas yang memadai untuk hal tersebut, dengan begitu maka proses pembelajaran akan terhambat yang seharusnya sebelum dimulainya pembelajaran tersebut fasilitas pendukung harus tersedia lebih dahulu. Kemudian selanjutnya terletak pada proses adaptasi pembelajaran, peserta didik yang tadinya cenderung berinteraksi langsung dalam pembelajaran akan memerlukan berbagai macam adaptasi belajar serta memahami pembelajaran yang di modelkan dalam jaringan, sehingga kebijakan yang diberikan bisa saja menimbulkan mandeknya pemahaman peserta didik terhadap pembelajaran. Mengigat bahwa perubahan ke pembelajaran online secara 'tidak langsung berpengaruh terhadap daya serap peserta didik 
(Dewi, W.A.F: 2020). Oleh karenanya, bahwa peserta didik harus didasari oleh berbagai pengalaman belajar agar pembelajaran secara online menjadi lebih fleksibel (Zapalska, A. and Brozik, D. :2006).

Pokok permasalahan bagi peserta didik tersebut bermuara pada perubahan lingkungan pembelajaran dari offline ke online sehingga dibutuhkan hal-hal yang harus menarik minat belajar online peserta didik melalui penciptaan lingkungan belajar yang positif; membangun komunitas belajar; memberikan umpan balik yang konsisten secara tepat waktu; dan menggunakan teknologi yang tepat untuk mengirimkan konten yang tepat. (Chakraborty:2014)

Dampak selanjutnya tentu terletak pada tenaga pengajar atau guru.sebagai seorang pendidik tentunya memiliki tanggung jawab terhadap proses pembelajaran peserta didiknya, namun akibat dari pandemic covid-19 dan berlakunya kebijakan WFH maka proses pembelajaran ikut terdampak dikarenakan beberapa hal yang menjadi hambatan bagi guru untuk melakukan proses pembelajaran secara online.

\section{a. Keterbatasan Pengetahuan Tekhnologi}

Keterbatasan penggunaan tekhnologi menjadi hambatan yang signifikan bagi proses

pembelajaran yang dilakukan oleh guru, hal tersebut dikarenakan masih banyaknya guru-guru senior atau yang sudah berumur namun tidak melek terhadap penggunaan tekhnologi pembelajaran berbasis online tersebut. Sehingga seharusnya terlebih dahulu diperlukan proses pelatihan untuk para guru-guru dalam peningkatan kapasitas mengajar berbasis media online tersebut.

\section{b. Keterbatasan Sarana dan Prasarana}

Fasilitas sebagai penunjang dalam proses pembelajaran tidak boleh terhambat. Keterbatasan sarana dan prasarana tentunya akan berdampak pula terhadap proses transfer pengetahuan. Dampak dari kebijakan bekerja dari rumah membuat banyaknya tenaga pendidik yang sedari awal bertatap muka langsung menyebabkan ketersediaan perangkat online tidak memadai. Sehingga seharusnya persiapan perangkat seperti laptop, jaringan, handphone harus dipersiapkan agar proses pemberian materi menjadi lebih baik.

\section{c. Keterbatasan Pengalaman Pembelajaran Online}

Proses pembalajaran yang selama ini dilakukan sebelum pandemi tentunya membuat guru sangat minim dalam pembelajaran secara online. Hal tersebut akan berdampak pada proses penyampaian materi juga penyampaian pemahaman kepada peserta didik, yang berakibat pada tidak efektifnya pembelajaran. Guru yang dari awal melakukan proses tatap muka justru kemudian di paksa untuk memberikan pelajaran melalui perangkat internet. Sehingga bisa saja berdampak pada kejenuhan ataupun kebosanan guru sehingga malas untuk memberikan pembelajaran kepada peserta didiknya. 
Itulah yang menjadi hambatan pada guru terkait pembelajaran yang diinstruksikan oleh kebijakan menteri pendidikan tersebut. Bisa saja, seiring dengan proses adaptasi hambatanhambatan tersebut bisa di minimalisir, namun dampak-dampak yang telah ditimbulkan akibat pandemic dengan kebijakan seperti itu disisi lain telah berpengaruh besar terhadap proses pembelajaran siswa.

Dampak selanjutnya dirasakan oleh para orang tua peserta didik. Dimulai dari dampak adanya biaya tambahaan untuk menyediakan fasilitas, baik itu berupa perangkat keras semisal komputer maupun handphone atau perangkat pendukung jaringan internet berupa paket kuota. Dengan begitu, maka secara otomatis beban pengeluaran keluarga pun akan bertambah. Selanjutnya adalah para orang tua dipaksa beradaptasi dan melakukan pendampingan pembelajaran anak-anaknya, sehingga mereka harus meluangkan waktu ketika anak-anak tersebut belajar secara online, sehingga aktivitas sehari-hari ataupun pekerjaan akan terdampak pula. Namun, dibalik itu terdapat Kendala lain yang ditemukan yakni kemampuan orang tua untuk memberikan fasilitas pendidikan online (Obiakor \& Adeniran: 2020) mereka yang hanya berprofesi petani dan tidak melek tekhnologi tentunya akan merasa kesulitan dalam pendampingan peserta didik.

\section{KESIMPULAN}

Dapat kita pahami bersama bahwa pandemic covid-19 telah memaksa seluruh sector untuk bertransformasi secara tiba-tiba untuk mengakimodir kegiatan-kegiatan yang berbasis ofdline menuju kepada online, lahirnya kebijakan MENDIKBUD untuk bekerja dari rumah dan belajar dari rumah menjadi salah satu upaya menjaga masyarakat dari pandemi. Namun, di satu sisi kebijakan tersebut telah berdampak banyak pada proses pendidikan baik bagi siswa, maupun guru dan juga keluarga atau orang tua. Pokok permasalahan utama terletak pada ketidaksisapan fasilitas, pengetahuan maupun kurangnya pengalaman, sehingga dibutuhkan waktu untuk beradaptasi dan menyebabkan keterlambatan proses pembelajaran, serta perbedaan kondisi wilayah yang belum kesemuanya dapat dijangkau internet secara menyeluruh. Oleh karenanya, perlu kiranya dilakukan pembaruan model pendidikan yang sesuai dengan kondisi pandemic namun tidak menimbulkan dampak pada proses pembelajaran, misalnya melakukan pembelajaran kontekstual yang berbasis kehidupan sehari-hari peserta didik.

\section{DAFTAR PUSTAKA}

Aji, R.H.S. (2020). Dampak Covid-19 pada Pendidikan di Indonesia: Sekolah, Keterampilan, dan Proses Pembelajaran, SALAM; Jurnal Sosial \& Budaya Syar-i 7 (5)

Caroline Hodges Persell. (1979). Educations and Inequality, The Roots and Results of Strattification in America's Schools (Pertama). United States of America: The Free Press.

Chakraborty, M. and Muyia Nafukho, F. (2014), "Strengthening student engagement: what do students want in online courses?", European Journal of Training and Development, Vol. 38 No. 9, pp. 782-802. https://doi.org/10.1108/EJTD-11-2013-0123 
Dewi, W. A. F. (2020). Dampak Covid-19 Terhadap Implementasi Pembelajaran Daring.

Obiakor, T., \& Adeniran, A. (2020). Covid-19: Impending Situation Threatens To Deepen Nigeria'S Education Crisis. Center For The Study Of The Economies Of Africa.

Purwanto, A., dkk (2020) Studi Eksploratif Dampak Pandemi COVID-19 Terhadap Proses Pembelajaran Online di Sekolah Dasar. EduPsyCouns Journal: Journal of education, Psychology, and Counseling.

Wekke, I. S., \& Saleh, A. M. (2020, August 11). Pembelajaran di Masa Pandemi: Tidak Hanya Metode Daring Saja. https://doi.org/10.31219/osf.io/njtku n

Zapalska, A. and Brozik, D. (2006), "Learning styles and online education", Campus-Wide $\begin{array}{llllll}\text { Information } & \text { Systems, } & \text { Vol. } 23 & \text { No. } & 5, & \text { pp. }\end{array}$ https://doi.org/10.1108/1065074061071408 0 